\title{
THE EFFECT OF COMPOST COMBINED WITH PHOSPHATE SOLUBILIZING BACTERIA AND NITROGEN-FIXING BACTERIA FOR INCREASING THE GROWTH AND YIELD OF CHILI PLANTS
}

\author{
Hayati Nur* \\ Faculty of Agriculture, University of Tadulako \& Postgraduate Program, \\ Faculty of Agriculture, University of Brawijaya, Indonesia \\ Sudiarso, Prijono Sugeng, Aini Nurul \\ Faculty of Agriculture, University of Brawijaya, Indonesia \\ *E-mail: nur.hayatirais@yahoo.com
}

\begin{abstract}
The effect of compost combined with phosphate solubilizing bacteria and nitrogen-fixing bacteria on chili plants has been investigated in an experiment using polybag. This research aims to examine the roles of phosphate solubilizing bacteria, nitrogen-fixing bacteria, and compost in increasing the growth and yield of chili plants. This research used a randomized block design with a two-factor factorial design consisting of R0: without Microbes, R1: Nitrogen-Fixing Bacteria (NFB), R2: Phosphate solubilizing bacteria + nitrogen-fixing bacteria (PSB + NFB). The second factor was a dose of organic fertilizer (compost), consisting of 4 dose levels, i.e.: P0: Control (Urea, SP-36, KCl), P1: $15 \mathrm{t} \mathrm{ha}^{-1}$ compost, P2: $20 \mathrm{t} \mathrm{ha}{ }^{-1}$ compost, P3: $25 \mathrm{t} \mathrm{ha}^{-1}$ compost. The research results showed that the use of compost at a dose of $20 \mathrm{t} \mathrm{ha}^{-1}$ added by PSB and NFB significantly increased the growth (number of branches, number of leaves, leaf area, chlorophyll content, plant dry weight) and yield (number of fruits, weight of fruits) of chili plants. The average number of chili fruits increased from 37 fruits per plant to 78 fruits per plant.
\end{abstract}

\section{KEY WORDS}

Compost, phosphate solubilizing bacteria, nitrogen-fixing bacteria, chili.

Increase in population and the growing number of industries requiring chili raw materials causes the need for chili to increase every year. Agricultural statistics data in 2018 noted that harvested area and national chili productivity increased, but chili productivity was still far below its production potential. National harvested area of chili was 120,847 ha with the productivity of $8.65 \mathrm{t} \mathrm{ha}^{-1}$ in 2015 and was 123,404 ha with the productivity of $8.47 \mathrm{t} \mathrm{ha}^{-1}$ in 2016. Chili harvested area in Central Sulawesi was 844 ha with the productivity of $6.44 \mathrm{t}$ ha $^{-1}$ in 2015 and was 872 ha with the productivity of $5.45 \mathrm{t} \mathrm{ha}^{-1}$ in 2016 .

Low organic matter content, water availability, and nutrient availability, as well as high air temperature (average air temperature is $26-35^{\circ} \mathrm{C}$ and in extreme conditions the air temperature can reach $\pm 37^{\circ} \mathrm{C}$ ) and low air humidity $( \pm 65 \%)$, are factors able to influence low chili productivity in Palu Valley. As with other plants, chili plants will not provide maximum results if the environmental conditions give no supports, for example, low water and nutrient availability and poor soil structure. Therefore, efforts need to be made to improve cultivation technology that can support the growth and yield of chili plants in Palu Valley.

Benefits of organic fertilizer (compost) addition into the soil are to increase nutrients, restore soil properties through increased soil water content, soil organic carbon, cation exchange capacity (CEC) and $\mathrm{pH}$, improve soil structure, aeration, and water-holding capacity, influence or regulate soil temperature, and enhance plant growth and production (Agegnehu et al. 2016; Karimuna et al. 2016; Zaman et al. 2016; Anhar et al. 2018). 


\section{METHODS OF RESEARCH}

This research was conducted in Bulupountu Jaya Village, Biromaru District, Sigi Regency, Central Sulawesi Province, from November 2014 to April 2015.

This research was conducted using a Randomized Block Design (RBD) with a twofactor factorial design. The first factor was selective soil microbes ( 2 best treatments were chosen) obtained from phase I research, consisting of 3 levels, i.e.: $R_{0}$ : without (PSB + NFB), $R_{1}$ : Nitrogen-fixing bacteria (NFB), $R_{2}$ : Phosphate solubilizing bacteria + Nitrogen-fixing bacteria (PSB + NFB). The second factor was organic fertilizer (compost) consisting of 4 dose levels, i.e.: $\mathrm{P}_{0}$ : Control (Urea, SP-36, $\left.\mathrm{KCl}\right), \mathrm{P}_{1}$ : compost $\left(15 \mathrm{t} \mathrm{ha}^{-1}\right), \mathrm{P}_{2}$ : compost $(20 \mathrm{t}$ ha $\left.{ }^{1}\right), \mathrm{P}_{3}$ : compost $\left(25 \mathrm{t} \mathrm{ha}{ }^{-1}\right)$. Of these two factors, 12 treatments with 3 replications were obtained, so there were 36 experimental units. Each treatment unit was represented by 8 plants in a polybag. Thus, there were 288 plants in this research.

The seeds to be sown were soaked in warm water $\left( \pm 50^{\circ} \mathrm{C}\right)$ for 1 hour (Sumarni et al. 2005). The immersion aimed to eliminate pests or diseases attached to the seeds and to speed up germination. The chili seeds were sown in $5 \times 8 \mathrm{~cm}$ polybags containing mixed media (soil + sand + compost $=1: 1: 1$ ). The seedbeds were placed in the shade and watered every day with enough water. The seeds were considered ready to be planted at 4 weeks after seedling or had 3-4 leaves. Before the seeds were transplanted, sorting was done to select healthy and uniform seeds.

After the seeds germinated and the seedlings were 4 weeks old in the seedbeds, the seedlings were transplanted to $35 \mathrm{~cm} \times 40 \mathrm{~cm}$ polybags containing mixed media of soil and compost (without compost, $15 \mathrm{t} \mathrm{ha}^{-1}, 20 \mathrm{t} \mathrm{ha}^{-1}$, and $25 \mathrm{t} \mathrm{ha}^{-1}$ ), which has been arranged according to the treatments with a polybag distance of $60 \mathrm{~cm} \times 50 \mathrm{~cm}$.

Inorganic fertilizer (urea, SP-36, and $\mathrm{KCl}$ ) application was performed when the plants were 7 days old after transplanting for the control treatment $\left(R_{0} P_{0}\right)$. Organic fertilizer (compost) application was carried out when filling polybags and adjusted to the dose of compost treatment to be tested, i.e. $15 \mathrm{t} \mathrm{ha}^{-1}, 20 \mathrm{t} \mathrm{ha}^{-1}$, and $25 \mathrm{t} \mathrm{ha}^{-1}$. Application of soil microbes was conducted on chili plants by applying $15 \mathrm{ml}$ of soil microbial isolates namely phosphate solubilizing bacteria (Bacillus subtilis and Pseudomonas fluorescens) and nitrogen-fixing bacteria (Azotobacter sp.) or according to the treatments on $25 \mathrm{~g}$ of compost as a carrier medium. Each polybag was given $25 \mathrm{~g}$ of compost applied with soil microbes (bio-compost) and given at planting.

The first chili harvest was done at the age of 80 days after planting, gradually with 4 days harvest intervals. Chili fruits were harvested after the fruits had $a \geq 80-100 \%$ red color.

To determine the effect of the treatment given, observations were conducted on plant growth and yield. Components observed were growth component, yield component, and soil microbial analysis.

1. Growth component consisting of: number of branches, number of leaves, leaf area, plant dry weight, and leaf chlorophyll content; per plant;

2. Yield component consisting of: flowering speed, number of fruits, and weight of fruits

3. Soil microbial analysis.

Observation data were analyzed by the $\mathrm{F}$ test. In terms of significant differences between treatments, the results were further tested using Tukey's Honestly Significant Difference (HSD) test at $5 \%$.

\section{RESULTS OF STUDY}

The results of HSD test at an $\alpha$ of 0.05 on the number of branches (Table 1) show that the R1P2 (NFB + $20 \mathrm{t} \mathrm{ha}^{-1}$ compost) treatment had the highest average number of branches of 17 branches. It was significantly different from other treatments but not significantly different from the $R_{1} P_{3}, R_{2} P_{2}$, and $R_{2} P_{3}$ treatments. 
Table 1 - Responses of Chili Plant Growth to phosphate solubilizing bacteria, nitrogen-fixing bacteria, and compost application

\begin{tabular}{|c|c|c|c|c|c|}
\hline Treatment & $\begin{array}{c}\text { Number } \\
\text { of branches }\end{array}$ & $\begin{array}{c}\text { Number of } \\
\text { leaves }\end{array}$ & $\begin{array}{c}\text { Leaf area } \\
\left(\mathrm{cm}^{2} \text { plant }{ }^{-1}\right)\end{array}$ & $\begin{array}{c}\text { Leaf chlorophyll content } \\
\text { (SPAD unit) }\end{array}$ & $\begin{array}{l}\text { Dry weight } \\
\left.\text { (g plant }^{-1}\right)\end{array}$ \\
\hline $\mathrm{R}_{0} \mathrm{P}_{0}$ & $6^{a}$ & $42^{a}$ & $380.80^{a}$ & $55.90^{a}$ & $7.03^{a}$ \\
\hline $\mathrm{R}_{0} \mathrm{P}_{1}$ & $8^{a b c}$ & $51^{b}$ & $565.00^{b}$ & $61.80^{\mathrm{bc}}$ & $8.13^{a}$ \\
\hline $\mathrm{R}_{0} \mathrm{P}_{2}$ & $11^{\mathrm{cd}}$ & $56^{\mathrm{cd}}$ & $753.01^{\mathrm{cd}}$ & $67.20^{\text {def }}$ & $7.67^{a}$ \\
\hline $\mathrm{R}_{0} \mathrm{P}_{3}$ & $10^{\mathrm{bc}}$ & $56^{\mathrm{cd}}$ & $776.74^{\mathrm{cd}}$ & $66.06^{\text {cde }}$ & $8.55^{\mathrm{ab}}$ \\
\hline $\mathrm{R}_{1} \mathrm{P}_{0}$ & $7^{\mathrm{ab}}$ & $49^{b}$ & $424.88^{a}$ & $60.90^{a b}$ & $7.79^{a}$ \\
\hline $\mathrm{R}_{1} \mathrm{P}_{1}$ & $8^{a b c}$ & $56^{\mathrm{cd}}$ & $688.15^{\mathrm{C}}$ & $71.43^{\mathrm{gn}}$ & $7.37^{a}$ \\
\hline $\mathrm{R}_{1} \mathrm{P}_{2}$ & $17^{1}$ & $66^{1}$ & $930.22^{\mathrm{ef}}$ & $74.13^{n}$ & $10.97^{\mathrm{DC}}$ \\
\hline $\mathrm{R}_{1} \mathrm{P}_{3}$ & $14^{\mathrm{ef}}$ & $62^{\text {ef }}$ & $911.25^{\mathrm{ef}}$ & $69.33^{\text {detgh }}$ & $11.91^{\mathrm{cd}}$ \\
\hline $\mathrm{R}_{2} \mathrm{P}_{0}$ & $9^{\mathrm{bC}}$ & $53^{b c}$ & $554.31^{b}$ & $64.33^{\text {bcd }}$ & $9.05^{\mathrm{ab}}$ \\
\hline $\mathrm{R}_{2} \mathrm{P}_{1}$ & $13^{\mathrm{de}}$ & $60^{\text {de }}$ & $818.82^{\text {de }}$ & $68.83^{\operatorname{detg}}$ & $10.77^{b c}$ \\
\hline $\mathrm{R}_{2} \mathrm{P}_{2}$ & $16^{\text {ef }}$ & $66^{\dagger}$ & $994.87^{\dagger}$ & $72.33^{\mathrm{gh}}$ & $13.97^{d}$ \\
\hline $\mathrm{R}_{2} \mathrm{P}_{3}$ & $16^{\text {ef }}$ & $62^{\mathrm{ef}}$ & $839.38^{\mathrm{de}}$ & $70.13^{\text {etgh }}$ & $13.46^{d}$ \\
\hline
\end{tabular}

Numbers followed by different letters in the same column indicate differences in the HSD test level at an $\alpha$ of 0.05 between treatment combinations of $R 0=$ Without soil microbes, $R 1=$ application of NFB, $R 2=$ application of PSB $+N F B, P O=$ Without compost, $P 1=$ Compost dose of 15 tha ${ }^{-1}, P 2=$ Compost dose of $20 t^{2} a^{-1}, P 3=$ Compost dose of 25 tha $^{-1}$.

Table 1 also shows that the $R_{1} P_{2}$ (NFB +20 t ha- 1 compost) and $R_{2} P_{2}$ (PSB $+N F B+$ $20 \mathrm{t} \mathrm{ha}^{-1}$ compost) treatments had the same highest average number of leaves of 66 leaves. It was significantly different from other treatments but not significantly different from the $R_{1} P_{3}$ and $\mathrm{R}_{2} \mathrm{P}_{3}$ treatments. Likewise, on the observation of leaf area, the $\mathrm{R}_{2} \mathrm{P}_{2}$ treatment showed the highest average leaf area of $994.87 \mathrm{~cm}^{2}$ plant ${ }^{-1}$. It was significantly different from other treatments but not significantly different from the $R_{1} P_{2}$ and $R_{1} P_{3}$ treatments.

The results of HSD test at an $\alpha$ of 0.05 on plant dry weight (Table 1) show that the $\mathrm{R}_{2} \mathrm{P}_{2}$ treatment had the highest average plant dry weight of $5.36 \mathrm{~g}$. It was significantly different from other treatments but not significantly different from the $\mathrm{R}_{0} \mathrm{P}_{2}$ treatment. This illustrates that the soil microbial activity (PSB + NFB) applied will increase by $20 \mathrm{t} \mathrm{ha}^{-1}$ compost application. Thus, the treatment can fulfill nutrient needs in chili plants. Additionally, the highest average chlorophyll content was obtained from the $R_{1} P_{2}$ (74.13 SPAD units) treatment and the lowest average chlorophyll content was obtained from the $R_{0} P_{0}(55.90$ SPAD units) treatment.

Figure 1 shows that there was a tendency for a faster flowering speed of chili plants reaching $50 \%$, i.e. 26 days after transplanting in the $R_{1} P_{2}$ (NFB +20 t hat compost), $R_{2} P_{2}$ (PSB + NFB +20 t ha $^{-1}$ compost $)$, and $\mathrm{R}_{1} \mathrm{P}_{3}\left(\mathrm{NFB}+20 \mathrm{t} \mathrm{ha}^{-1}\right.$ compost) treatments.

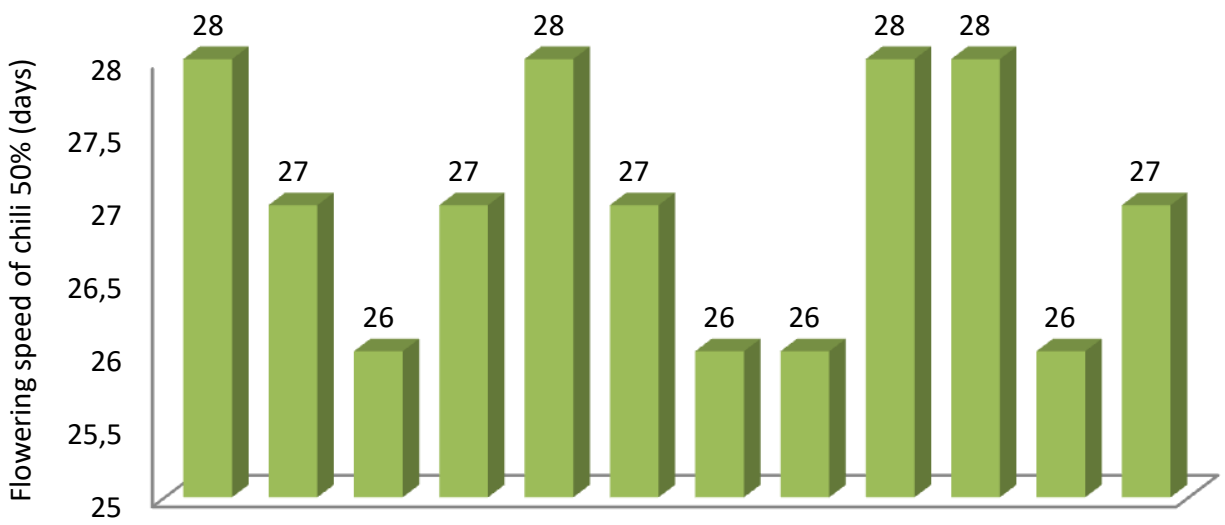

ROP0 ROP1 ROP2 ROP3 R1P0 R1P1 R1P2 R1P3 R2P0 R2P1 R2P2 R2P3

Treatment

Figure 1 - Average Flowering Speed of Chili Plants (50\%) 
The results of HSD test at $\alpha$ of 0.05 on the number of fruits of chili plants (Table 2) show that the $R_{2} P_{2}$ (PSB $+N F B+20 t$ ha $^{-1}$ compost) treatment had the highest average number of fruits of 78 fruits $\left(1^{\text {st }}-10^{\text {th }}\right.$ harvest). It was significantly different from other treatments.

Table 2 - Responses of Chili Plant Yield to phosphate solubilizing bacteria, nitrogen-fixing bacteria, and compost application

\begin{tabular}{ccc}
\hline Treatment & Number of fruits (fruit plant $\left.{ }^{-1}\right)$ & ${\text { Weight of fruits }\left(g \text { plant }^{-1}\right)}^{\text {a }}$ \\
\hline $\mathrm{R}_{0} \mathrm{P}_{0}$ & $52^{\mathrm{cd}}$ & $106.19^{\mathrm{ab}}$ \\
$\mathrm{R}_{0} \mathrm{P}_{1}$ & $54^{\mathrm{cd}}$ & $130.62^{\mathrm{c}}$ \\
$\mathrm{R}_{0} \mathrm{P}_{2}$ & $44^{\mathrm{ab}}$ & $107.46^{\mathrm{ab}}$ \\
$\mathrm{R}_{0} \mathrm{P}_{3}$ & $53^{\mathrm{cd}}$ & $129.78^{\mathrm{bc}}$ \\
$\mathrm{R}_{1} \mathrm{P}_{0}$ & $37^{\mathrm{a}}$ & $100.75^{\mathrm{a}}$ \\
$\mathrm{R}_{1} \mathrm{P}_{1}$ & $49^{\mathrm{bc}}$ & $128.85^{\mathrm{bc}}$ \\
$\mathrm{R}_{1} \mathrm{P}_{2}$ & $63^{\mathrm{et}}$ & $170.02^{\mathrm{d}}$ \\
$\mathrm{R}_{1} \mathrm{P}_{3}$ & $67^{\dagger}$ & $194.16^{\mathrm{e}}$ \\
$\mathrm{R}_{2} \mathrm{P}_{0}$ & $57^{\mathrm{de}}$ & $116.77^{\mathrm{abc}}$ \\
$\mathrm{R}_{2} \mathrm{P}_{1}$ & $53^{\mathrm{cd}}$ & $128.96^{\mathrm{bc}}$ \\
$\mathrm{R}_{2} \mathrm{P}_{2}$ & $78^{\mathrm{g}}$ & $206.59^{\mathrm{e}}$ \\
$\mathrm{R}_{2} \mathrm{P}_{3}$ & $65^{\dagger}$ & $163.22^{\mathrm{d}}$ \\
\hline
\end{tabular}

Numbers followed by different letters in the same column indicate differences in the HSD test level at an $\alpha$ of 0.05 between treatment combinations of $R 0=$ Without soil microbes, $R 1=$ application of NFB, $R 2=$ application of $P S B$ $+N F B, P O=$ Without compost, $P 1=$ Compost dose of $15 t$ ha ${ }^{-1}, P 2=$ Compost dose of 20 tha ${ }^{-1}, P 3=$ Compost dose of $25 t$ ha $^{-1}$.

The highest average weight of chili fruits per plant (Table 2) was found in the $R_{2} P_{2}$ (PSB+NFB $+20 \mathrm{t} \mathrm{ha}^{-1}$ compost) treatment of $206.59 \mathrm{~g}$. It was significantly different from other treatments but not significantly different from the $R_{1} P_{3}$ treatment. The lowest weight of chili fruits was obtained in the $R_{1} P_{0}$ (NFB + without compost) treatment combination.

Figure 2 shows that the highest average number of harvested chili fruits was found in the $6^{\text {th }}$ harvest of the $R_{2} P_{2}$ treatment of 16 fruits, followed by the $7^{\text {th }}$ harvest of the $R_{1} P_{3}$ treatment of 13 fruits, and the $7^{\text {th }}$ harvest of the $R_{2} P_{3}$ treatment of 12 fruits, respectively.

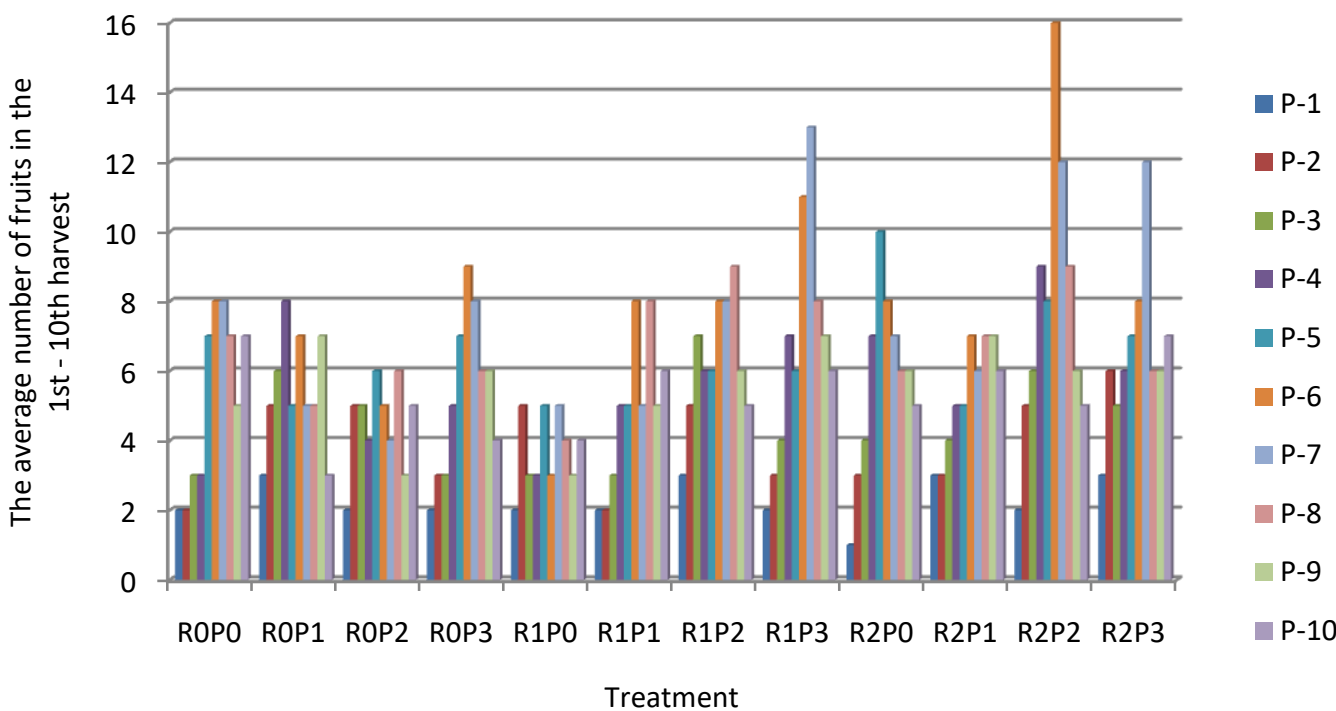

Figure 2 - Average Number of Fruits of Chili Plants in the $1^{\text {st }}-10^{\text {th }}$ Harvest

Soil microbial analysis results on the soil used in this research indicated that selective soil microbial treatment and compost doses caused an increase in the total soil microbial population before and after treatment. 
Table 3 - Soil Microbial Populations Before and After Treatment

\begin{tabular}{|c|c|c|c|c|}
\hline \multirow{2}{*}{ Treatment } & \multicolumn{2}{|c|}{$\mathrm{N}$-fixing bacteria population (CFU $\mathrm{ml}^{-1}$ ) } & \multicolumn{2}{|c|}{ Phosphate solubilizing bacteria population $\left(\mathrm{CFU} \mathrm{ml}{ }^{-1}\right)$} \\
\hline & Before treatment & After treatment & Before treatment & After treatment \\
\hline $\mathrm{R}_{0} \mathrm{P}_{0}$ & $1.12 \times 10^{\prime}$ & $1.34 \times 10^{\prime}$ & $6.07 \times 10^{4}$ & $11.30 \times 10^{4}$ \\
\hline $\mathrm{R}_{0} \mathrm{P}_{1}$ & $1.12 \times 10^{\prime}$ & $5.36 \times 10^{\prime}$ & $6.07 \times 10^{4}$ & $15.00 \times 10^{4}$ \\
\hline $\mathrm{R}_{0} \mathrm{P}_{2}$ & $1.12 \times 10^{\prime}$ & $5.13 \times 10^{\prime}$ & $6.07 \times 10^{4}$ & $14.30 \times 10^{4}$ \\
\hline $\mathrm{R}_{0} \mathrm{P}_{3}$ & $1.12 \times 10^{7}$ & $2.23 \times 10^{7}$ & $6.07 \times 10^{4}$ & $10.20 \times 10^{4}$ \\
\hline $\mathrm{R}_{1} \mathrm{P}_{0}$ & $1.12 \times 10^{\prime}$ & $3.68 \times 10^{\prime}$ & $6.07 \times 10^{4}$ & $15.40 \times 10^{4}$ \\
\hline $\mathrm{R}_{1} \mathrm{P}_{1}$ & $1.12 \times 10^{7}$ & $4.69 \times 10^{7}$ & $6.07 \times 10^{4}$ & $11.90 \times 10^{4}$ \\
\hline $\mathrm{R}_{1} \mathrm{P}_{2}$ & $1.12 \times 10^{7}$ & $11.90 \times 10^{7}$ & $6.07 \times 10^{4}$ & $14.40 \times 10^{4}$ \\
\hline $\mathrm{R}_{1} \mathrm{P}_{3}$ & $1.12 \times 10^{\prime}$ & $6.81 \times 10^{\prime}$ & $6.07 \times 10^{4}$ & $10.20 \times 10^{4}$ \\
\hline $\mathrm{R}_{2} \mathrm{P}_{0}$ & $1.12 \times 10^{\prime}$ & $4.80 \times 10^{\prime}$ & $6.07 \times 10^{4}$ & $14.20 \times 10^{4}$ \\
\hline $\mathrm{R}_{2} \mathrm{P}_{1}$ & $1.12 \times 10^{7}$ & $8.26 \times 10^{7}$ & $6.07 \times 10^{4}$ & $23.20 \times 10^{4}$ \\
\hline $\mathrm{R}_{2} \mathrm{P}_{2}$ & $1.12 \times 10^{\prime}$ & $11.40 \times 10^{\prime}$ & $6.07 \times 10^{4}$ & $15.60 \times 10^{4}$ \\
\hline $\mathrm{R}_{2} \mathrm{P}_{3}$ & $1.12 \times 10^{\prime}$ & $4.35 \times 10^{\prime}$ & $6.07 \times 10^{4}$ & $14.40 \times 10^{4}$ \\
\hline
\end{tabular}

$R 0=$ no $(P S B+N F B), R 1=$ application of NFB, R2 = application of $P S B+N F B, P O=$ without compost, $P 1=15 t$ ha ${ }^{-1}$ compost, $P 2=20 t$ ha ${ }^{-1}$ compost, $P 3=25 t$ ha $a^{-1}$ compost .

Table 3 shows that the highest total microbial population was found in the $\mathrm{R}_{1} \mathrm{P}_{2}$ (NFB + $20 \mathrm{t} \mathrm{ha}^{-1}$ compost) treatment, followed by the $\mathrm{R}_{2} \mathrm{P}_{2}$ (PSB $+\mathrm{NFB}+20 \mathrm{t}$ ha ${ }^{-1}$ compost) treatment, the $R_{2} P_{1}$ (PSB $+N F B+15 t$ ha ${ }^{-1}$ compost) treatment, and the $R_{1} P_{3}$ (NFB +25 t ha ${ }^{1}$ compost) treatment respectively.

\section{DISCUSSION OF RESUTS}

The growth and yield of chili plants are strongly influenced by the role of organic matter (compost) in increasing applied selective soil microbial activity. Application of $20 \mathrm{t} \mathrm{ha} \mathrm{h}^{-1}$ compost combined with phosphate solubilizing bacteria and nitrogen-fixing bacteria application can increase the growth and yield of chili plants. Besides being able to increase nutrients in the soil, organic matter or compost can also increase microorganism activity, enhance humus levels, and improve soil structure (Frimpong et al. 2017; Agbede et al. 2017).

At the beginning of growth, the effect of compost and selective soil microbial application was not evident in all observation variables. It was probably due to shoot dominance at the beginning of growth, causing the branching of chili plants at the beginning of growth to not indirectly form intensively. According to Taiz and Zeiger (2002), apical dominance can inhibit lateral bud growth. Thus, the increase in number of branches at the beginning of growth will also be inhibited.

Increase in branch formation has a significant effect on the increase in number of leaves, leaf area, and plant dry weight. Increase in number of leaves and leaf area will influence photosynthesis process occurring in chloroplasts inside the leaves. Plant dry weight in the form of total biomass is a manifestation of metabolic processes occurring in the plant's body, in which dry weight can indicate plant productivity because $90 \%$ of photosynthesis results are in plant dry weight (Gardner et al. 1991).

The treatment of nitrogen-fixing bacteria and phosphate solubilizing bacteria application combined with $20 \mathrm{t} \mathrm{ha}^{-1}$ compost application in this research was not only able to increase plant growth, but also increase chili plant yield. Table 2 shows that the highest number of fruits and weight of fruits of chili plants were obtained in the treatment of nitrogenfixing bacteria and phosphate solubilizing bacteria application combined with $20 \mathrm{t} \mathrm{ha}^{-1}$ compost application. It is supported by Wiguna's statement (2011) that one way to increase the production of red chili plants is by using environmentally friendly fertilization such as biofertilizers and organic fertilizers (Elekhtyar et al. 2017; Frimpong et al. 2017). Organic fertilizers and bio-fertilizers with various processes support each other in fertilizing the soil and at the same time conserving and nourishing soil ecosystems as well as avoiding the possibility of environmental pollution. In addition to increasing nutrient content in the soil, organic fertilizers also contain a number of growth-regulating substances and vitamins needed to stimulate plant growth and microorganisms (Khan et al. 2017; Coa et al. 2017). 
These research results also showed that $20 \mathrm{t} \mathrm{ha}^{-1}$ compost application can increase soil microbial population (Table 3). It is in line with Pranoto et al.' (2015) research stating that organic matter has a positive effect on the increase in Azotobacter $s p$ population. Thus, it can be interpreted that $20 \mathrm{t}$ ha-1 compost application will influence the increase in microorganism activity (phosphate solubilizing bacteria and nitrogen-fixing bacteria) in the soil so that nutrient availability in the soil, especially the $\mathrm{N}$ and $\mathrm{P}$ elements, will also increase (Xiaohou et al. 2008; Hernández et al. 2014; Barajas-Aceves 2016).

\section{CONCLUSION}

The use of compost at a dose of $20 \mathrm{t}$ ha- 1 combined with the PSB and NFB application significantly increased the growth and yield of chili plants. Soil microbial analysis results showed that nitrogen-fixing bacteria increased from $1.12 \times 10^{7} \mathrm{CFU} \mathrm{ml}{ }^{-1}$ to $8.26 \times 10^{7} \mathrm{CFU}$ $\mathrm{ml}^{-1}$ and phosphate solubilizing bacteria increased from $6.07 \times 10^{4} \mathrm{CFU} \mathrm{ml}^{-1}$ to $23.20 \times 10^{4}$ $\mathrm{CFU} \mathrm{ml^{-1 }}$. Additionally, the average number of chili fruits increased from 37 fruits per plant to 78 fruits per plant.

\section{REFERENCES}

1. Agbede TM, Adekiya AO, Eifediyi EK, 2017. Impact of poultry manure and NPK Fertilizer on soil physical properties and growth and yield of carrot. J Hort Res. 25: 81-88

2. Agegnehu G, Nelson P, Bird M, 2016. Crop yield, plant nutrient uptake and soil physicochemical properties under organic soil amendments and nitrogen fertilization on nitisols. Soil Tillage Res. 160: 1-13

3. Anhar A, Junialdi R, Zein A., 2018. Growth and tomato nutrition content with Bandotan (Ageratum Conyzoides L) bokashi applied. IOP Conf Ser Mater Sci Eng. Vol 335.

4. Barajas-Aceves $M, 2016$. Organic waste as fertilizer in semiarid soils and restoration in mine sites. In: organic fertilizers-from basic concepts to applied outcomes. InTech. 243$271 \mathrm{p}$.

5. Cao Y, Ma Y, Guo D, Wang Q, Wang G, 2017. Chemical properties and microbial responses to biochar and compost amendments in to soil under continuous watermelon cropping. Plant Soil Enveron. 63(1):1-7.

6. Elekhtyar NM, Mikhael BB, Wissa MT, 2017. Utilization of compost and compost tea for improving egyptian hybrid rice one cultivar. J.Sus.Agric.Sci. 43 (3): pp.141- 149.

7. Frimpong K.A, 2017. Influence of Compost on Incidence and Severity of Okra Mosaic Disease and Fruit Yield and Quality of Two Okra (Abelmoschus esculentus L. Moench) Cultivars. International Journal of Plant \& Soil Science. 16(1): 1-14.

8. Hernández MIS, Gómez-Álvarez R, Rivera-Cruz M del C, Cruz R, Álvarez-Solís JD, PatFernández JM, 2014. The influence of organic fertilizers on the chemical properties of soil and the production of Alpinia purpurata. Cienc e Investig Agrar. 41:215-224.

9. Karimuna L, Rahni NM, Boer D, 2016. The use of bokashi to enhance agricultural productivity of marginal soils in Southeast Sulawesi, Indonesia. J Trop Crop Sci. 3: 1-6.

10. Khan A.A, H. Bibi, Z. Ali, M. Syarif, S.A. Syah, H.Ibadullah, K. Khan, I. Azem and S.Ali, 2017. : Effect of compost and inorganic fertilizers on yield and quality of tomato. Academia Journal of Agricultural Research 5(10): 287-293

11. Pranoto E., S. Pratiwi. H.Wahyuni dan S. Anindita 2015. Pola Sebaran Azotobacter sp. dan Bahan Organik pada Berbagai Kelas Kemiringan Lereng Perkebunan Teh Dataran Tinggi PPTK Gambung. J.Biospecies 8(1):33-41

12. Sumarni, N., A. Hidayat, dan E. Sumiati 2006. Pengaruh Tanaman Penutup Tanah dan Mulsa Organik terhadap Produksi Cabai dan Erosi Tanah. J. Hort. 16(3):197-201

13. Xiaohou S, Min T, Ping J, Weiling C, 2008. Effect of EM Bokashi application on control of secondary soil salinization. J Water Sci Eng. 1:99-106

14. Zaman M, Ahmed M, Gogoi P, 2016. Effect of bokashi on plant growth, yield and essential oil quantity and quality in Patchouli (Pogostemon Cablin Benth.). Biosci. Biotechnol. Res. Asia. 7:383-387. 